\title{
The History of Computer Science and Technology Reflection of a reflection: a (peer) review.
}

\author{
Camille Akmut
}

\begin{abstract}
This review article - a reflection of a reflection - concludes our series of studies on the social conditions of computer science and technology. (One further article, currently still being written, will appear.) It is given here in the hopes that it will create a thousand more new researchers on these many, varied problems, questions - all of which open. (Originally "A hundred references to create a thousand more researchers", we fear we may not have been able to achieve that goal - but all the same.) Peer review, but not in the intended sense however : for, them are us too..
\end{abstract}


To Jean Cavailles (1903-1944)

"A philosopher-mathematician loaded with explosives, a tenacious realist, resolute without optimism. If that is not a hero, what is?" (Canguilhem)

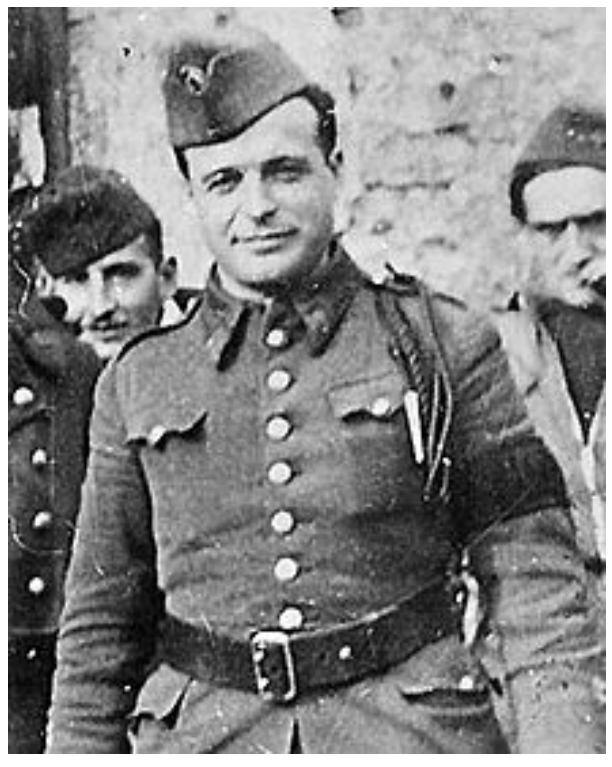




\section{Primary sources (read explicitly : open questions and problems)}

We must "muddle" with our times, and what(ever) they bring. If one wishes to do anything original in this century. False notions : "proper" research (for proper people), "real" sources (for sometimes unreal people), or "proper" methodologies (for not-always-so proper gentlemen and gentlewomen of scholarly concerns, and too often priorities), and all the rest of things that are so many shackles to all of us, including those who put them on others in their real false beliefs. Others may and will continue to conceive of their offices as places of undisturbed leisurely activities, the retreat of the pure mind, paid reading and recreational writing rooms in so many words, only disturbed by the hours of noon and four - lunch with the colleagues, boy-oh-boy do they love lunch with the colleagues, where many things are heard, and better not repeated for their sake, if only lunch could make up their whole day, a task they sometimes even manage by an arithmetic whose mysteries only our historians of science will be able to tellthe bottom is bottomless.

\section{Writings by computer scientists}

1. http://ai.eecs. umich.edu/people/conway/conway.html

Description The writings of Lynn Conway (1938-) : pioneer of VLSI (Very large-scale integration) architecture. (Fired by IBM - a company that now practices diversity with a capital letter - because she was a transgender woman.*)

${ }^{*}$ who, by some miracle, had escaped the fate of almost all of the other transgender women of her times : and, that is - our proper readers will pardon us, the rest already know - street or brothel prostitution.

2. http://www . aaronsw . com/weblog/fullarchive

Description "Full archives" of the blog of Aaron Swartz (1986-2013) ("Full archives", not quite : the older blog (entries), going as far back as 2002, if we remember correctly, is (are) only accessible through archive.org). 3. https://twitter.com/aaronsw

Description Twitter account of Aaron Swartz (1986-2013). (Who will finally write the biography of Aaron Swartz that he and we all deserve?)

\section{Scientific journals}

4. Communications of the ACM

Description A treasure trove for historians. (Forsythe, Knuth, algorithms, etc..)

5. Journal of Functional Programming

Description Primary journal for functional programming. ("Who's Who" in the world of functional programmers/theorists.)

\section{Legal documents}

6. "UNITED STATES OF AMERICA v. AARON SWARTZ". 
Description We have long, long not reached a good understanding of the circumstances of USA v. Swartz. (The cowards, we know.)

\section{Books and articles}

6. Goldstine, Herman. 1993. The Computer from Pascal to Neumann. Princeton : Princeton University Press.

Description A first reference, especially regarding the second World War period (Herman Goldstine had worked on ENIAC). (The old model of the computer scientist-turned historian, by default.)

7. Abbate, Janet. 2012. Recoding Gender. Women's Changing Participation in Computing.

Description The most important of her works as far as we are concerned. (Women used to be everywhere in/around computing.)

8. Abbate, Janet. 1999. Inventing The Internet. Cambridge, MA : MIT Press.

Description Another notable work of hers. (A most needed complement to Where Wizards Stay Up Late.)

9. Hicks, Marie. 2017. Programmed Inequality: How Britain Discarded Women Technologists and Lost Its Edge in Computing.

Description The same as Abbate 2012 but different. (But, the same everywhere we go : women have been purged from "tech".)

10. Akmut, Camille. 2018 [2017]. "Social conditions of outstanding contributions to computer science : a prosopography of Turing Award laureates (1966-2016)."

Description The equivalent of the Nobel Prize in computer science. (In retrospect the article we care for the least, but the one that was the most important, it got us started, so get started. (We do not remember which historian, despite possessing all the right credentials to do a "grand" academic career, we believe in the economic/rural history of England, had made a huge mistake right off the bat in his first, receiving an appropriate backlash from his elders : but, that is $O K$, we do our best, and not much worse can come out of it but start we must. (Hacker ethic.)))

11. Hodges, Andrew. 2014. Alan Turing: The Enigma. Princeton : Princeton University Press.

Description the reference biography. (Avoid the other one, below.)

12. Huang, Andrew. 2013. Hacking the Xbox. An Introduction to Reverse Engineering. San Francisco : No Starch Press.

Description One of the most important hardware hackers (read : computer scientists) of our times. (The "material" that got him a letter from MIT, who were already long cowards back then.)

13. Rossiter, Margaret. 1993. "The Matthew Matilda Effect in Science" Social Studies of Science 23 : 325-341.

Description (What happens) When men attribute to themselves the ideas of their fellow women scientists (or are attributed, and stay quiet). 14. Rossiter, Margaret. 1982; 1995; 2012. Women Scientists in America. (Vol. 1 : "Struggles and Strategies to 1940". Vol. 2 : "Before Affirmative Action, 1940-1972". Vol. 3 : "Forging a New World Since 1972".) 
Description So that the histories of computer science and technology from now on will include women, also, but not only (all those, who, whatever their minority characteristics, have thus far been excluded from history, including that of science). (The "Lynn Conway" effect.)

15. Copeland, Jack. 2012. Turing. Pioneer of the Digital Age. Oxford : Oxford University Press.

Description A most queer philosopher out of New Zealand (New Zealand again) : here is an idea, the Martians may have killed Turing, let's look in all the wrong places, except the obvious ones, just so we can be sure. (The times of Alan Turing killed Alan Turing.)

16. Daylight, Edgar. 2014. "A Turing Tale" Communications of the ACM 57(10): 36-38.

Description One of the most promising historians of computer science - if he would only turn to the issues of his times.

17. Daylight, Edgar. 2015. "Towards a Historical Notion of 'Turing-the Father of Computer Science" History and Philosophy of Logic 36(3) : 205-228.

Description Another article by him, but read the many others.

18. Lecuyer, Christophe. 2006. Making Silicon Valley. Innovation and the Growth of High Tech, 1930-1970. Cambridge, MA : MIT Press.

Description Absolutely fascinating book, if that is not real economic and social history applied to technology, then what is. (Probably, our favorite book after Recoding Gender and Tim Berners-Lee's.)

19. Lee, J.A.N. 1995. Computer Pioneers. Los Alamitos : IEEE Computer Society Press.

Description If this isn't a perfect source for prosopography, then we don't know prosopography (a fancy word for collective biography). (This to say that we admit that biography, understood as that term is as applying to one person, has limitations, and much more can be learned by taking a group of interconnected people together (network).)

20. Lovelace, Ada. 1843. Notes to "Sketch of the Analytical Engine invented by Charles Babbage" In Scientific Memoirs 3, edited by Richard Taylor, 666-731. London : Richard and John E. Taylor.

Description The famous text. (She probably wasn't the first programmer, as much as we would want.)

21. Misa, Thomas, ed. 2017. Communities of Computing: Computer Science and Society in the ACM. New York : Association for Computing Machinery.

Description an important compendium on the social aspects of computing.

22. Levy, Steven. 2010. Hackers: Heroes of the Computer Revolution. Sebastopol, CA : O'Reilly Media.

Description The "original" hackers. (Not the whole story.)

23. Akmut, Camille. 2019. "Hackers Revisited : the "original "hackers"". Clever solutions, political acts."

Description More open problems. (Reinserting political and social elements where they have been removed.) 
24. Williams, Sam. 2002. Free as in Freedom: Richard Stallman's Crusade for Free Software. Sebastopol, CA : O'Reilly Media.

Description An important social-political movement of our times.

25. Berners-Lee, Tim. 1999. Weaving the Web: The Original Design and Ultimate Destiny of the World Wide Web by Its Inventor. San Francisco, CA : Harper San Francisco.

Description The Web was invented as a way to further humanity. (Not a way to further companies' "profit-oriented" - as economics textbooks euphemistically put - priorities.)

26. Hafner, Katie and Lyon, Matthew. 1998. Where Wizards Stay Up Late: The Origins of the Internet. New York, NY : Touchstone.

Description The most popular history of the Internet. (The old model of the journalist-turned historian, by default, also, but for how long.)

27. Morrill, John. 1995. "A Nobel Prize in Mathematics" The American Mathematical Monthly 102(10) : 888-892.

Description why there isn't a Nobel Prize in mathematics, while, in our case, we don't have to look for long (computer science is too young).

\section{Textbooks (computer science)}

Contrary to the naive notions of a certain professor (though only in title, no more than the clothes of a philosopher make a fool a philosopher, no more than a mathematician or computer scientist can give anyone a royal road to their discipline), we are not abstracted from "muddling" with the material of computer scientists. They are simultaneously the materials of our times. At least once in your lives take intellectual risks, if not your lives proper. (They would have never been a Jean Cavailles - not in a thousands years, we all know that (what).)

28. Aho, Alfred, Sethi, Ravi and Ullman, Jeffrey. 1986. Compilers: Principles, Techniques, and Tools. Reading, MA : AddisonWesley.

Description The reference book on compilers (preceded by an older).

29. Knuth, Donald. 1997. The Art of Computer Programming. Fundamental Algorithms. Volume 1. Third edition. Reading, MA : Prentice-Hall.

Description The first volume of this important sum is a "traversal one", and the most general and hence should be the priority.

30. Donovan, Alan and Kernighan, Brian. 2015. The Go Programming Language. New York : Addison-Wesley.

Description When computer scientists turn a blind eye to the social characteristics of their employer, as they now so often do. (Holds a "genealogical" tree of the origins of this particular language.)

31. Mead, Carver and Conway, Lynn. 1980. Introduction to VLSI Systems. Reading, MA : Addison-Wesley.

Description The reference book on VLSI. 
32. Kurose, James and Ross, Keith. 2017. Computer Networking: A Top-Down Approach. Harlow : Pearson Education.

Description One of two important books on networks. (What we have described elsewhere as an "upside-down pudding".)

33. Tanenbaum, Andrew. 2003. Computer Networks. Upper Saddle River, NJ : Pearson Education.

Description The other important book on this topic. (Though lacking in many ways, as the others.)

\section{Newspapers and misc.}

When working at the edge and frontier of our culture, that of our times, the reading of newspapers becomes and is an indispensable activity. We cannot rely on hundred years of sure scholarship, but we do our best with what we have: and, plenty is available and of good standard (many academics, who should, do not talk about these topics, these gentlemen and gentlewomen presumably resent lowering themselves to our times, of which they have extracted themselves in many other ways, preferring instead to focus on the 16th or 17th century that they have somehow managed to fashion in their feeble minds as places of higher intellectual activity, an untold mystery to everyone except themselves).

\section{The Guardian}

Description Critical articles - in an industry of computer-related publishings that are notoriously uncritical - on various topics related to technology : e.g. tax evasion, "New Zealand" schemes, "Indian reservations", worse galore. (The bottom is bottomless.)

\section{ProPublica}

Description Non-profit investigative journalism primarily concerned with U.S. affairs. (E.g. series on "algorithmic inequality".)

36. The Intercept

Description Another "fearless" investigative publication. (E.g. articles such as "The Wiretap Rooms", or the ones by Micah Lee.)

37. Hacker News

Description A good place to start, to keep up with the latest trends. (Y Combinator, Paul Graham.)

38. Computer History Museum

Description An institution dedicated to computer history e.g. oral interviews, primary sources, etc. 


\section{Methodologies}

39. Piketty, Thomas. Capital in the 21st century.

Description (The greatest living economist) misses the mark on technology, and simulteanously and necessarily the 21st century.

40. Stone, Lawrence. 1971. "Prosopography" Daedalus 100(1) : 46-79.

Description The reference text on prosopography (i.e. collective biography).

41. Wittgenstein, Ludwig. Tractatus Logico-Philosophicus.

Description "The limits of our language are the limits of our world". (Language : In the end, no matter what field we choose to engage in, it all comes down to language, as one soon discovers and realizes - we cannot escape it - no matter if computer science, mathematics, economics or whatever else...).

42. Galbraith, John. The Great Crash, 1929. [Including an introduction by James Galbraith on the "Great Crisis" of 2008]

Description The (new) old cowboys of the financial world.

43. Canguilhem, Georges. 2011-? (ongoing?). Oeuvres completes. Paris : Vrin.

Description His complete works, composed of many large volumes (currently 5), still not translated in English, an incalculable loss for the scientific, and not only community at large. (Georges Canguilhem, who, in all other ways, incarnated the figure of the intellectual to perfection - titles, clothing, language, though not manners with some, those he saw as losing his time - had left in many places of his otherwise academic work thousands of unforgiving judgments on the institutions, ideas and people of his time, that were remnants, reminiscences or reflections of his simple origins and involvement with the French Resistance, as a doctor of - not letters or philosophy - but medicine. Another meteorite fallen from the sky.) In particular volume 1, Ecrits philosophiques et politiques 1926-1939, give an insight into his more political writings - and philosophical, though both were interlinked. Such, that our understanding of him is only half.

44. Durkheim, Emile. 1956. Education and Sociology. New York : Simon and Schuster.

Description Family and education are two main sources of explanation for the behaviors of people, "nothing explains more than them" says Durkheim in this work. (A topic our professors would rather avoid, who come themselves increasingly from the same backgrounds as our elites, and cannot quite be rightfully said to come "from the people", a reality that is source of countless consequences on their abstract science.)

45. Engels, Friedrich and Marx, Karl. [1846] The German Ideology.

Description Our boys "went off" back in the days before The Capital. (The Brother Bauer's probably stopped writing after that.) The most acute description of the relationships between intellectual and economic forms of domination. (Jeff Bezos owns the Washington Post.)

46. Ettling, John. 1981. The Germ of Laziness. Rockefeller Philanthropy and Public Health in the New South. Cambridge, MA : Harvard University Press. 
Description Our elites prefer concentrating on philanthropy - and have done so for decades - to obfuscate or avoid the topic of taxes. (Cf. Rutger Bregman's recent talk at the Davos forum.)

46. Siegmund-Schultze, Reinhard. 2001. Rockefeller and the Internationalization of Mathematics Between the Two World Wars. Basel : Birkhauser Verlag.

Description More philantropy, this time specifically applied to sciences. $($ more diversions $)($ philantropy $=$ diversion $)($ philantropy $=$ noTaxes $)$

\section{Visual documents (documentaries)}

47. Knappenberger, Brian. 2012. The Internet's Own Boy.

Description : what probably started it all, long ago. (Aaron Swartz.) 48. Klose, Simon. 2013. TPB AFK: The Pirate Bay Away from Keyboard.

Description : that, or this. (If only our - their - justice was as diligent with bankers.)

49. Puttonen, Hannu. 2001. The Code.

Description : this, or that. (A hacker never finishes a program.) (Or Revolution $O S$ - same year, different country.)

50. Florin, Fabrice. 1984. Hackers: Wizards of the Electronic Age.

Description : "A hacker never finishes a program". (The other half left.) 


\section{Unsubmitted PhD thesis : Contributions towards a social computer science. (2019)}

—. 2018 [2017]. "Social conditions of outstanding contributions to computer science : a prosopography of Turing Award laureates (1966-2016). Draft".

-. 2019. "Minerva and Virgil - a program (Notes on Karpathy et al. 2014)".

-. 2019b. "A User-Defined Web. And, on Systems modification in general."

-. 2019c. "Notes on the Freedom Tower. Current issues in Networking (mesh)."

—. 2019d. "Hackers Revisited : the "original "hackers"”. Clever solutions, political acts."

—. 2019e. "Ensuring the integrity of research in the Age of open access. A proposal : hashing + public-key cryptography signing."

—. 2019f. "When doing good pays : A first research into the remuneration practices of non-profit executives (particularly the IT sector)."

—. 2019g. " "Not just a HR trend". Behind the curtains of diversity : a statistical analysis of role distribution and hiring practices at a technology company."

—. 2019h. "The perfect philosophy for the perfect generation. (Effective Altruism : everywhere but at home.)"

—. 2019i. "The Reinvention of Our Language. "material" = woman."

—. 2019j. "The lonely death of Aaron, the cowards at MIT."

—. 2019k. "The new "Uncle Tom"'s of Our New Media."

—. 20191. "The History of Computer Science and Technology. Reflection of a reflection : a (peer) review."

Social conditions of a work on computer science and technology :

- S. my second partner, "[they/she] who belongs to no one". (Her.) (A prison of gold is still a gold prison.)

- J. my best/oldest friend, who long before me had made her own Web, and may have inspired me to write mine. ("A User-Defined Web")

- Many of my mistakes are located on the left side (everything except politics), after an accident that rendered me partly blind in that eye. (Even the mistakes are beautiful.)

- Except for the first, all of my articles were written in less than a week, and many in much less time. (Could not sleep due to a small noisy room.) 